\title{
PENGARUH BEBERAPA JENIS MULSA ORGANIK TERHADAP PERTUMBUHAN DAN HASIL TANAMAN TERUNG (Solanum melongena $\mathrm{L}$ )
}

\section{The Influence Of Several Types Of Organic Mulch On The Growth And Yield Of Eggplant Crops (Solanum Melongena L)}

\author{
Yetnawati, Hasnelly \\ Program Studi Agroteknologi Fakultas Pertanian \\ Universitas Muara Bungo \\ Artikel Diterima 18 November 2020, disetujui 10 Januari 2021
}

\begin{abstract}
ABSTRAK
Penelitian ini dilaksanakan di Desa Sungai Abang, Kecamatan VII Koto Ilir dengan ketinggian tempat $\pm 90-175$ mdpl dengan jenis tanah Ultisol dengan $\mathrm{pH}$ 5,8-6,0 dan dengan rata-rata temperatur $22^{0} \mathrm{C}-33^{0} \mathrm{C}$ (Monografi Desa Sungai Abang, 2018). Penelitian dilaksanakan pada tanggal 25 Juli 2019 sampai 03 Nopember 2019. Tujuan penelitian ini adalah untuk mengetahui pengaruh berbagai jenis mulsa organik dan mendapatkan jenis mulsa organik yang terbaik untuk pertumbuhan dan produksi tanaman Terung (Solanum melongena $\mathrm{L}$ )

Penelitian ini menggunakan Rancangan Acak Kelompok (RAK) dengan 5 perlakuan yaitu : M0 (tanpa mulsa), M1 (mulsa jerami padi), M2 (mulsa Kirinyuh), M3 (mulsa Alangalang) dan M4 (mulsa petai cina). Parameter yang diamati yaitu tinggi anaman $(\mathrm{cm})$, jumlah cabang produktif (buah), jumlah buah pertanaman (buah), berat buah pertanaman (g) dan produksi (ton/ha). Data dianalisis secara statistik dengan menggunakan sidik ragam, bila berpengaruh nyata maka dilanjutkan dengan uji Duncan New Multiple Range Test (DNMRT) pada taraf $5 \%$.

Berbagai jenis mulsa organik tidak berpengaruh nyata terhadap pertumbuhan tanaman dan produksi tanaman Terung (Solanum melongena L). Mulsa jerami padi merupakan mulsa organik yang tepat untuk meningkatkan tinggi tanaman, jumlah buah pertanaman dan berat buah pertanaman serta produksi tanaman Terung (Solanum melongena $\mathrm{L}$ ).
\end{abstract}

Kata kunci : Mulsa Organik, Tanaman Terung, Pertumbuhan dan Hasil

ABSTRACT

This research was conducted in Sungai Abang Village, District VII Koto Ilir with a height of \pm 90-175 meters above sea level with ultisol soil type with a $\mathrm{pH}$ of 5.8-6.0 and with an average temperature of $22^{0} \mathrm{C}-33^{\circ} \mathrm{C}$ (Monograph of Sungai Abang Village, 2018). The research was conducted from July 25, 2019 to November 3, 2019. The purpose of this research is to find out the influence of various types of organic mulch and get the best type of organic mulch for the growth and production of eggplant plants (Solanum melongena L)

This study used RandomIzed Group Design (RAK) with 5 treatments namely: M0 (without mulch), M1 (rice straw mulch), M2 (Kirinyuh mulch), M3 (Reed mulch) and M4 (Chinese petai mulch). The observed parameters are the height of anaman $(\mathrm{cm})$, the number of productive branches (fruit), the number of crops (fruit), the weight of the crop ( $\mathrm{g}$ ) and production (ton / ha). The data was analyzed statistically using fingerprints, if it had a real effect then followed by duncan new multiple range test (DNMRT) at a level of 5\%.

Various types of organic mulch have no real effect on plant growth and eggplant production (Solanum melongena L). Rice straw mulch is the right organic mulch to increase 
the height of plants, the number of crops and the weight of crops and the production of eggplant (Solanum melongena L).

Keywords : Organic Mulch, Eggplant Plant, Growth and Yield

\section{PENDAHULUAN}

Terung (Solanum melongena L) adalah tanaman asli daerah tropis, tanaman ini berasal dari Asia Tenggara termasuk Indonesia. Terungmerupakan tanaman sayur-sayuran yang termasuk famili Solanaceae. Buah terung disenangi setiap orang baik sebagai lalapan segar maupun diolah menjadi berbagai jenis masakan. Dalam setiap $100 \mathrm{~g}$ bahan mentah terung mengandung 26 kalori, $1 \mathrm{~g}$ protein, 0,2 $\mathrm{g}$ hidrat arang, $25 \mathrm{IU}$ vitamin A, 0,04 g vitamin $\mathrm{B}$ dan $5 \mathrm{~g}$ vitamin C.Selain itu, terung juga mempunyai khasiat sebagai obat karena mengandung alkaloid solanin, dan solasodin yang berfungsi sebagai bahan baku kontrasepsi oral. Buah terung juga diekspor dalam bentuk awetan, terutama jenis terung jepang (Sunarjono, $d k k ., 2003)$.

Permintaan terhadap terung terus meningkat sejalan dengan pertambahan penduduk yang diikuti dengan meningkatnya kesadaran akan manfaat sayur-sayuran dalam memenuhi gizi keluarga, sehingga produksi tanaman terung perlu terus ditingkatkan. Produksi tanaman terung di Indonesia pada tahun 2017 mencapai 535.421 ton dengan luas panen sebesar 43.905 ha sehingga diperoleh produktivitas sebesar 12,19 ton/ha yang tersebar di 34 Provinsi di Indonesia. Di Provinsi Jambi produktivitas tanaman terung masih dibawah produktivitas tanaman secara nasional yaitu hanya 7,92 ton/ha dengan produksi sebesar 10.961ton dan luas panen $1.384 \mathrm{Ha}$ (BPS, 2018). Begitu juga di Kabupaten Tebo, produktivitas tana-man terung hanya mencapai 6,54 ton/ha dengan luaspanen hanya sebesar 66,5 ha dan produksi sebesar 435 ton (BPS Kabupaten Tebo, 2018). $\begin{array}{cccc}\text { Melihat fakta } & \text { tersebut } & \text { dapat } \\ \text { diambil kesimpulan } & \text { bahwa } & \text { terung } \\ \text { merupakan sayuran } & \text { yang cukup }\end{array}$ menjanjikan untuk diusahakan tetapi saat ini produktivitas terung masih sangat rendah. Rendahnya produkti-fitas tanaman terung ini antara lain disebabkan karena teknik budidaya yang belum optimal. Untuk mening-katkan produkivitas tanaman terung dapat dilakukan secara ekstensifikasi dan intensifikasi, namun dalam usaha peningkatan produktivitas dan efisiensi penggunaan tanah, cara intensifikasi merupakan pilihan yang tepat untuk diterapkan. Salah satu usaha tersebut adalah dengan memodifikasi iklim mikro melalui aplikasi mulsa organik.

Mulsa merupakan bahan yang potensial untuk mempertahankan suhu tanah, kelembaban tanah, kandungan bahan organik, mengura-ngi jumlah dan kecepatan aliran permukaan, meningkatkan penyera-pan air dan menekan pertumbuhan gulma. Mulsa adalah material penutup tanaman budidaya yang dimaksudkan untuk menjaga kelembaban tanah serta menekan pertumbuhan gulma dan penyakit sehingga membuat tanaman tumbuh dengan baik. Mulsa dapat berperan memperbaiki kondisi tanah dan gilirannya meningkatkan pertumbu-han dan produksi tanaman. Berdasar-kan sumber bahan dan cara pembuatannya, maka mulsa dapat dikelompokkan menjadi mulsa organik, anorganik dan kimia sintetik. Mulsa organik yaitu bahan sisa pertanian seperti jerami, batang jagung, daun kirinyuh, daun pisang, daun tebu, alang-alang, daun lamtoro (petai cina), serbuk gergaji, sekam padidan lain-lain (Umboh, 2002). 
Mulsa jerami padi dapat memberikan kelembaban menekan pertumbuhan gulma dan memper-lambat proses penguapan air tanah, memperbaiki kesuburan tanah, struktur, dan cadangan air tanah. Selain itu, mulsa jerami dapat menyangga (buffer) suhu tanah agar tidak terlalu panas dan dingin. Mayun, $d k k$, (2007) juga menyatakan bahwa mulsa jerami padi dapat mengurangi fluktuasi suhu, dan meningkatkan kelembaban dan mengurangi evapotranspirasi.

Pemanfaatan daun alang-alang sebagai mulsa merupakan alternatif yang potensial, karena alang-alang mudah tumbuh, cepat berkembang biak dan pada lahan marginal pun tumbuhan ini tumbuh dengan baik. Menurut Tri dan Kefi(2015), suhu pada lahan yang ditutupi mulsa alangalang lebih rendah sejalan dengan kadar lengas yang terjadi lebih tinggi dan menggambarkan ketersediaan air bagi tanaman, hal ini mengakibatkan porositas tanah lebih baik bagi keluar masuknya air dan udara secara bebas sehingga tanaman tumbuh lebih tinggi, meningkatnya luas daun, akibatnya fotosintesis bagi pertumbuhan vegetatif berjalan baik yang pada akhirnya mendukung pertum-buhan generatif. Sedangkan Pujisiswanto, (2011), mulsa alang-alang mampu memodifikasi iklim mikro yang dibutuhkan tanaman dan dapat mempertahankan kelembaban dan suhu tanah sehingga akar tanaman dapat menyerap unsur hara lebih baik.

Kirinyuh (Chromolaena odorata) merupakan tanaman liar yang berpotensi sebagai sumber bahan organik (pupuk hijau) yang ketersediaannya cukup melimpah dibeberapa sentra produksi tanaman sayuran. Hasil dekomposisi Kirinyuh dapat meningkatkan bahan organik tanah, memperbaiki agregat dan struktur tanah, meningkatkan Kapasi-tas Tukar Kation (KTK) serta menyediakan unsure hara Nitrogen, Fosfor, Kalium, Kalsium dan Magnesium (Suntoro, 2001).

Petai cina (Leucaena leucocephala L) yang lebih dikenal dengan Lamtoro telah lama dimanfaatkan sebagai pohon peneduh, pencegah erosi, sumber kayu bakar dan pakan ternak. Daun-daun petai cinajuga kerap digunakan sebagai mulsa dan pupuk hijau serta daun petai cina lekas mengalami dekomposisi (Badrunasar dan Nurahmah, 2012). Dekomposisi dari bahan mulsa organik dapat mensuplai unsur hara bagi tanaman dan juga kondisi lingkungan serta mempermudah mineral dari bahan organik untuk digunakan oleh tanaman (Damaiyanti $d k k ., 2013$ ).

Tujuan dari penelitian ini adalah untuk mengetahui pengaruh berbagai jenis mulsa organik dan mendapatkan jenis mulsa organik yang terbaik untuk pertumbuhan dan produksi tanaman Terung (Solanum melongena L). Hadi (2018) menyatakan bahwa mulsa organik (jerami padi, sekam padi dan serbuk gergaji) tidak berpengaruh nyata terhadap tinggi tanaman terung pada umur 15 HST dan $30 \mathrm{HST}$, jumlah buah/plot dan berat buah/plot, tetapi berpengaruh nyata terhadap tinggi tanaman terung pada umur 45 HST.

Berdasarkan uraian diatas maka penulis tertarik untuk melakukan penelitian dengan judul "Pengaruh Beberapa Jenis Mulsa Organik Terhadap Pertumbuhan Hasil Tanaman Terung (Solanum melongena $\mathrm{L}) "$.

\section{METODE PENELITIAN}

Penelitian ini dilaksanakan di Desa Sungai Abang, Kecamatan VII Koto Ilir dengan ketinggian tempat $\pm 90-175 \mathrm{mdpl}$ dengan jenis tanah Ultisol dengan $\mathrm{pH} 5,8$ 6,0 dan dengan rata-rata temperatur $22^{\circ} \mathrm{C}$ $33^{0} \mathrm{C}$ (Monografi Desa Sungai Abang, 2018). Bahan yang digunakan dalam penelitian ini adalah : mulsa jerami padi, mulsa kerinyuh, mulsa alang-alang dan mulsa petai cina, benih tanaman terung varietasRonggo, pupuk kandang dan pupuk NPK (15:15:15). Sedangkan Alat yang digunakan adalah cangkul,parang, sabit, meteran, jangka sorong, polybag, tali rapia, 
handspayer, pisau, ember, ajir, label, buku data serta alat tulis untuk mencatat hasil pengamatan.

Penelitian ini menggunakan Rancangan Acak Kelompok (RAK) dengan 5 perlakuan dan 4 kelompok. Adapun perlakuan tersebut yaitu : M0 (tanpa mulsa), M1 (Mulsa Jerami Padi), M2 (Mulsa Kerinyuh), M3 (Mulsa Alangalang), DAN M4 (Mulsa Petai Cina). Setiap perlakuan diulang sebanyak 4 kali sehingga jumlah seluruh petak percobaan adalah 20 petak percobaan. Tiap petak percobaan ada 6tanaman maka jumlah tanaman seluruhnya sebanyak 120 tanaman, dan setiap petak diambil 2 tanaman sebagai tanaman sampel. Denah percobaan dan tata letak tanaman dapat dilihat pada lampiran 1 dan 2 .

Persiapan lahan diawali dengan pengukuran lahan sesuai dengan yang di kehendaki, kemudian membersihkan lahan dari segala jenis gulma dilanjutkan pengolahan tanah pertama yaitu dengan cara di cangkul, pencangkulan pertama sedalam $30 \mathrm{~cm}$ yang berfungsi sebagai pemecahan bongkahan tanah agar tanah menjadi gembur. Lahan yang sudah diolah dibuat petak-petak percobaan dengan ukuran 1,2 x 1,8 m dan diberi pupuk kandang kambing 20 ton/ha (4,32 $\mathrm{kg} /$ petak). Kemudian dibuat lobang tanam dengan jarak $60 \mathrm{~cm}$ x $60 \mathrm{~cm}$. Jumlah populasi setiap petak terdapat 6 tanaman. Pemberian mulsa organik sesuai dengan jenis perlakuan yang dilakukan pada saat tanam. Mulsa organik di potong-potong kemudian disebar merata dalam bedengan dengan tebal $5 \mathrm{~cm}$ (Heryani, etal,. 2011).

Pemupukan yang dilakukan adalah pupuk kandang dengan dosis 20 ton/ha (4,32 kg/petak) sebagai pupuk dasar yang aplikasikan saat pengolahan lahan dan pupuk NPK (15:15:15)sebesar $200 \mathrm{~kg} / \mathrm{ha}$ (43,2 gr/petak) sebagai pupuk susulan, diberikan 2 kali yaitu pada saat tanam dan umur 30 hst, masing-masing setengah dosis dengan cara dikocorkan dekat tanaman. Pemeliharaan yang dilakukan adalah penyiraman, yang dilakukan 2 kali seharipagidan sore, jika terjadi hujan maka tidak dilakukan penyiraman, Pengendalian hama dan penyakit dilakukan dengan konsep pengendalian terpadu dengan melakukan pengamatan setiap hari, karena serangan sudah di atas ambang ekonomi maka dikendalikan dengan pestisida yang sesuai yaitu dengan menggunakan Basmex dengan dosis yang dilakukan pada pada umur 42 hst dan 56 hst. Adapun penyakit yang ditemui adalah busuk pangkal batang sehingga ada 2 batang tanaman terung yang mati pada umur 45 hst. Panen pertama dilakukan pada umur 50 hst, selanjutnya dilakukan selang seminggu sekali sebanyak 5 kali panen. Pemanenan dilakukan pada pagi dan sore hari, dengan cara memetik buah muda yang bijinya belum keras dan daging buahnya belum liat.

Data penunjang yang dilakukan adalah : Pengukuran suhu harian, pengukuran suhu dan kelembaban tanah. Sedangkan penamatan terhadap data utama yaitu berupa : tinggi tanaman $(\mathrm{cm})$, jumlah cabang produktif (buah), jumlah buah pertanaman (buah), berat buah per tanaman (g), dan produksi (ton/Ha). Untuk mengetahui pengaruh beberapa jenis mulsa dianalisis secara statistic dengan menggunakan analisis ragam, apabila berpengaruh nyata maka dilanjutkan dengan uji jarak Berganda Duncan Multipe Range Test (DMRT) pada taraf $5 \%$ (Steel and Torrie, 1994)

\section{HASIL DAN PEMBAHASAN Tinggi Tanaman $(\mathrm{cm})$}

Tinggi tanaman merupakan salah satu parameter pertumbuhan tanaman. Tanaman setiap waktu terus tumbuh yang menunjukkan telah terjadi pembelahan dan pembesaran sel. Tinggi tanaman merupakan ukuran tanaman yang mudah untuk diamati dan sering digunakan sebagai parameter untuk mengukur pengaruh dari lingkungan atau perlakuan (Guritno dan Sitompul, 1995). Untuk 
melihat dinamika pertumbuhan tinggi tanaman terung pada pengamatan setiap minggunya dari umur 14 sampai 42 hari setelah tanam dengan perlakuan pemberian berbagai jenis mulsa organik disajikan dalam bentuk Gambar 1 berikut :

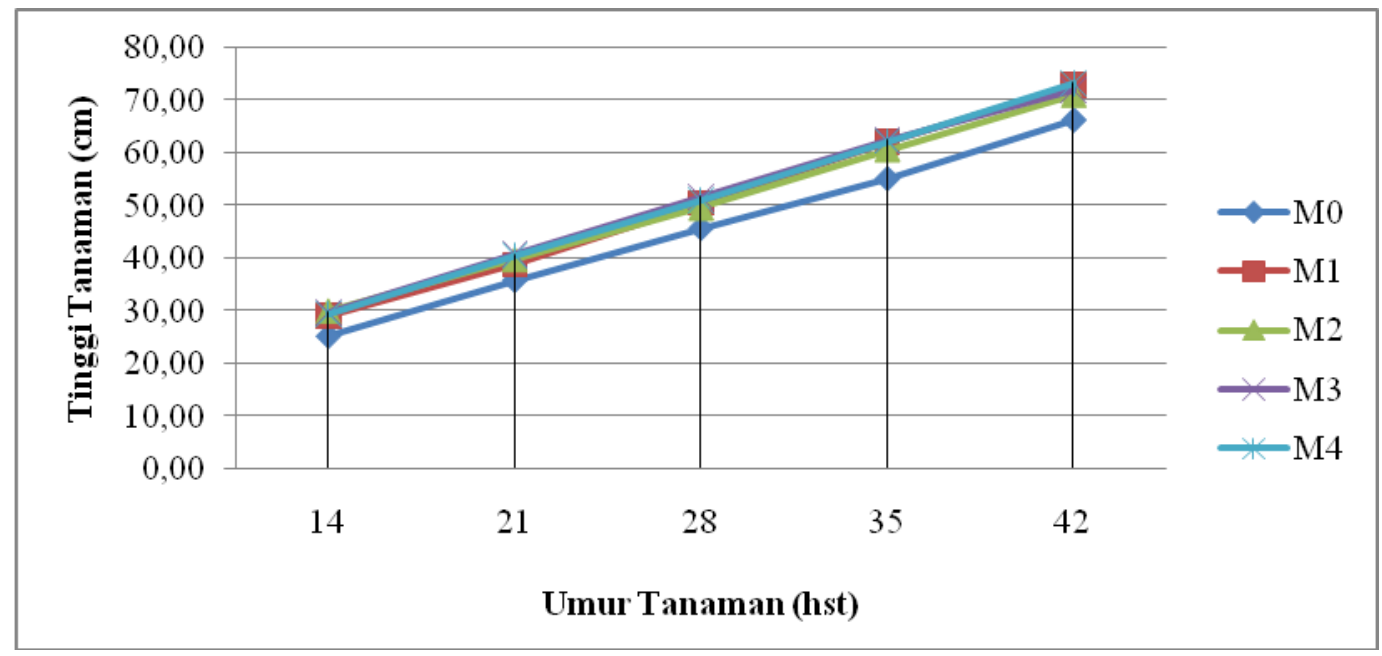

Gambar1. Grafik Tinggi Tanaman Umur 14-42 hari setelah tanam (hst)

Dari Gambar 1 diatas terlihat jelas bahwa masing-masing perlakuan pemberian berbagai jenis mulsa organik pada tanaman terung terjadi peningkatan tinggi tanaman pada setiap minggunya. Peningkatan tinggi tanaman terung pada pemberian berbagai mulsa organik memperlihatkan grafik yang sama dan tanpa kendala sampai akhir pengamatan umur 42 hstdan lebih baik dibandingkan tanpa mulsa organik (M0) yang pertumbuhan lambat.

Hasil analisis ragam menunjukkan bahwa pemberian beberapa jenis mulsa tidak berpenga-ruhnyata terhadap tinggi tanaman. Rataan tinggi tanaman terung pada pemberian beberapa jenis mulsa dapat dilihat pada Tabel

Tabel 1. Rataan Tinggi Tanaman Terung Pengaruh Beberapa Jenis Mulsa Organik Pada Umur 42 hst

\begin{tabular}{cc}
\hline Perlakuan & Rata-Rata $(\mathrm{cm})$ \\
\hline M0 & 66,25 \\
M1 & 72,94 \\
M2 & 71,00 \\
M3 & 72,06 \\
M4 & 73,38 \\
\hline
\end{tabular}

$\mathrm{KK}=4,76 \%$
Keterangan : Perlakuan tidak berpengaruh nyata terhadap tinggi tanaman $(\mathrm{P}>0,05)$

Tabel 1 menunjukan bahwa perlakuan beberapa mulsa organik tidak berpengaruh nyata terhadap tinggi tanaman terung secara statistik $(\mathrm{P}>0,05)$. Namun rataan tinggi tanaman yang dihasilkan lebih tinggi dari pemberian tanpa mulsa (M0). Hal ini diduga karena suhu tempat tumbuh tanaman sudah ideal untukpertumbuhan tanaman terung sehingga fungsi mulsa tidak lagi dimanfaatkan oleh tanaman. Hal ini sejalan dengan pernyataan Wisudawati (2016), bahwa pening-katan suhu hingga batas optimal dapat menaikkan hasil bersih fotosintesis, tetapi pada batas suhu maksimal hasil tersebut menurun tajam karena terjadi peningkatan respirasi. Pada suhu optimum bagi mikroba efektivitasnya meningkat untuk mengurai bahan organik menjadi unsur yang dapat diserap oleh akar tanaman.

Berdasarkan pengamatan penunjang pada penelitian ini, rata-rata suhu harian pada pagi hari mencapai $23,26^{0} \mathrm{C}$ dan siang hari $33,05^{\circ} \mathrm{C}$, sedangkan suhu tanah pada penelitian ini yaitu pada perlakuan tanpa mulsa bekisar antara $\pm 24,12^{0} \mathrm{C}$ pada pagi, 32,55 pada 
siang dan 30,80 pada sore hari sedangkan pada perlakuan pemberian mulsa berkisar antara $\pm 24,12^{0} \mathrm{C}-24,14^{0} \mathrm{C}$ pada pagi hari, $32,31^{0} \mathrm{C}-32,48^{0} \mathrm{C}$ dan $30,66^{0} \mathrm{C}-30,83^{\circ} \mathrm{C}$ pada sore hari. Hal ini berarti bahwa lingkungan tumbuh tanaman terung, baik yang diberi mulsa maupun tanpa mulsa organik memiliki suhu tanah yang sama.

Secara umum, suhu dan kelembaban tanah merupakan unsur yang berpengaruh terhadap pertum-buhan tanaman. Menurut Umboh (2002), suhu tanah akan mempe-ngaruhi suhu akar yang selanjutnya akan dipindahkan pada bagian tana-man lainnya. Hal itu tentunya akan mempengaruhi proses fisiologi tanaman. Lebih lanjut Lakitan (2011), suhu tanah akan dipengaruhi oleh jumlah serapan radiasi matahari oleh permukaan tanah.

\section{Jumlah Cabang Produktif (buah)}

Hasil analisis ragam menun-jukkan bahwa pemberian beberapa jenis mulsa tidak berpengaruh nyata terhadap jumlah cabang produktif. Rataan jumlah cabang produktif tanaman terung pada pemberian beberapa jenis mulsa dapat dilihat pada Tabel 2.

Tabel 2. Rataan Jumlah Cabang Produktif Tanaman Terung Pengaruh Beberapa Jenis Mulsa Organik

\begin{tabular}{cc}
\hline Perlakuan & Rata-Rata (buah) \\
\hline M0 & 5,00 \\
M1 & 5,00 \\
M2 & 5,50 \\
M3 & 6,38 \\
M4 & 5,63 \\
\hline
\end{tabular}

$\mathrm{KK}=13,86 \%$

Keterangan : Perlakuan tidak berpengaruh nyata terhadap tinggi tanaman $(\mathrm{P}>0,05)$

Tabel 2 menunjukan bahwa perlakuan beberapa mulsa organik tidak berpengaruh nyata terhadap jumlah cabang produktif tanaman terung secara statistik $(\mathrm{P}>0,05)$. Hal ini karena suhu/iklim dan kelemba-ban tanah yang relatif sama setiap perlakuan baik perlakuan tanpa mulsa (M0) maupun perlakuan dengan beberapa mulsa organik (M1, M2, M3 dan M4)
Selain pengaruh timbal balik antar unsur iklim/cuaca, fluktuasi unsur iklim/cuaca juga dipengaruhi oleh faktor lingkungan lainnya. Rumakuway $d k k$ (2016), juga me-nyatakan bahwa kelembaban dan temperatur tanah pada siang dan malam hari tidak jauh berbeda mengakibatnya peranan mulsa sebagai pengatur kelembaban dan suhu tanah tidak menunjukkan peranan yang maksimal. Hamdani (2009) juga melaporkan bahwa suhu tanah pada tanaman kentang tanpa mulsa dan mulsa jerami pada pagi hari tidak berbeda. Lebih lanjut Nurdin $d k k$ (2015) menyatakan bahwa mulsa akan terlihat pengaruhnya, apabila kondisi lingkungan tumbuh mengalami cekaman kekeringan.

Selain itu faktor lingkungan seperti cahaya matahari juga mempengaruhi pertumbuhan tana-man terung. Menurut Sarief (2001) pertumbuhan tanaman disamping memerlukan media tumbuh yang baik dan tersedianya air yang cukup, tanaman juga memerlukan keadaan lingkungan dan cahaya yang cukup. Hal ini sangat penting bagi kelang-sungan proses-proses metabolisme fotosintesis dan respirasi. Lebih lanjut menurut Gardner $e t$ al. (1991), bahwa percabangan merupakan fungsi genetikyang berinteraksi dengan faktor lingkungan.

\section{Jumlah Buah Pertanaman (buah)}

Hasil analisis ragam menun-jukkan bahwa pemberian beberapa jenis mulsa tidak berpengaruh nyata terhadap jumlah buah pertanaman. Rataan jumlah buah pertanaman terung pada pemberian beberapa jenis mulsa dapat dilihat pada Tabel 3.

\section{Tabel 3. Rataan Jumlah Buah Pertanaman Terung Pengaruh Beberapa Jenis Mulsa Organik}

\begin{tabular}{cc}
\hline Perlakuan & Rata-Rata (buah) \\
\hline M0 & 7,13 \\
M1 & 8,00
\end{tabular}




\begin{tabular}{cc} 
M3 & 8,88 \\
M4 & 6,50 \\
\hline $\mathrm{KK}=18,45 \%$ & \\
\hline
\end{tabular}

Keterangan : Perlakuan tidak berpengaruh nyata terhadap tinggi tanaman $(\mathrm{P}>0,05)$

Tabel 3 menunjukan bahwa perlakuan beberapa mulsa organik tidak berpengaruh nyata terhadap jumlah buah pertanaman terung secara statistik $(\mathrm{P}>0,05)$. Hal ini diduga lingkungan tumbuh yang sudah subur dan kebutuhan air yang mencukupi sehingga pemberian berberapa mulsa organik tidak terlihat pengaruhnya terhadap jumlah buah pertanaman.

Hal ini terlihat dari sifat masingmasing mulsa organik yang diuji, dimana mulsa organik seperti mulsa kirinyu (M2) dan mulsa petai cina diduga sudah terdekomposisi dan terurai sempurna dan menambah unsur hara, tetapi unsur hara sudah berlebih atau tanaman berada pada keadaan luxuri (mewah) sehingga pertumbuhan tanaman terung dapat berjalan dengan optimal yang berdampak pada jumlah buah pertanaman terung tersebut. Lakitan (2011), menjelaskan jika jaringan tanaman mengandung unsur hara tertentu, dengan konsentrasi yang lebih tinggi dari konsentrasi yang dibutuhkan untuk pertumbuhan maksimum, maka pada kondisi ini dikatakan tanaman dalam kondisi konsumsi mewah (luxury consumption). Pada konsentrasi yang terlalu tinggi unsur hara esensial dapat menyebabkan ketidakseimbangan penyerapan unsur hara lain pada proses metabolisme tanaman.

Sedangkan pada mulsa jerami padi (M1) dan mulsa alang-lang (M3) yang merupakan mulsa yang sulit terurai dan sifat fisik kedua mulsa ini masih terlihat sampai panen terakhir sehingga masih bisa mempertahankan unsur hara dan ketersediaan air yang mencukupi. Gusmini $d k k$ (2008), menyatakan bahwa sumber bahan organik yang diperlakukan sebagai mulsa seperti alang-alang dan jerami padi, dapat mempengaruhi sifat-sifat fisik, dan hara setelah melapuk, dapatjuga berfungsi memperbesar ketersediaan air tanah, penyerapan air lebih optimal. Hakim et al (1986), bahwa bila tanah cukup mengandung air dan udara, penguraian bahan organic berlangsung cepat.

\section{Berat Buah Per Tanaman (g)}

Análisis ragam menunjukkan bahwa pemberian beberapa jenis mulsa berpengaruh nyata terhadap berat buah pertanaman. Rataan jumlah buah pertanaman terung pada pemberian beberapa jenis mulsa dapat dilihat pada Tabel 4.

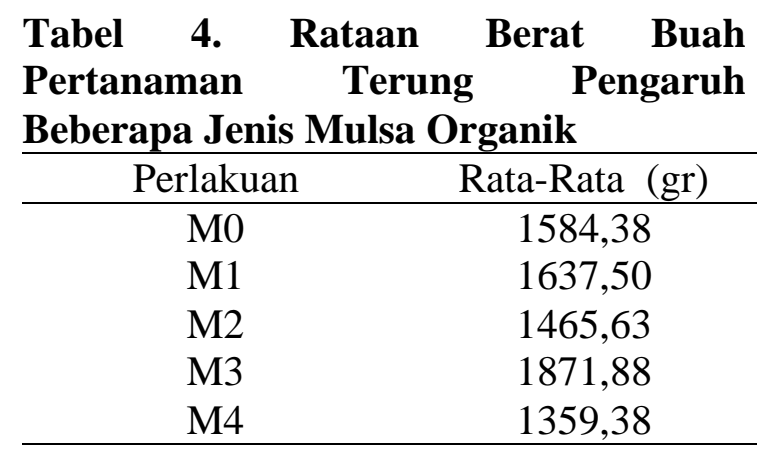

$\mathrm{KK}=19,08 \%$

Keterangan : Perlakuan tidak berpengaruh nyata terhadap tinggi tanaman $(\mathrm{P}>0,05)$

Tabel 4 juga menunjukan bahwa perlakuan beberapa mulsa organik tidak berpengaruh nyata terhadap berat buah pertanaman terung secara statistik $(\mathrm{P}>0,05)$. Dilihat dari rataan yang dihasilkan maka dapat dijelaskan bahwa jumlah buah yang banyak, menghasilkan berat buah yang banyak pula yang disebabkan oleh unsur hara yang tersedia dan kadar air yang mencu-kupi pada setiap perlakuan merupa-kan penyebab utama dari berat buah pertanaman terung.

Faktor lingkungan seperti sinar matahari juga mempengaruhi pertumbuhan tanaman terung. Surtinah (2008), mengemukakan bahwa cahaya matahari sangat menentukan proses fotosintesis dan dari proses fotosintesis inilah karbohidrat akan dihasilkan. Sedang-kan Hardjowigeno (2007), menyata-kan bahwa 
efisiensi nutrisi tanaman meningkat apabila permukaan tanah dilindungi dengan bahan organik.

Produksi (ton/Ha)
Análisis ragam menunjukkan bahwa pemberian beberapa jenis mulsa tidak berpengaruhnyata terha-dap produksi. Rataan produksi terung pada pemberian beberapa jenis mulsa dapat dilihat pada Tabel 5.

Tabel 5. Rataan Produksi Terung Pengaruh Beberapa Jenis Mulsa Organik

\begin{tabular}{lcc}
\hline \multirow{2}{*}{\multicolumn{1}{c}{ Perlakuan }} & Produksi Per Petak & Produksi Per Hektar \\
\cline { 2 - 3 } & $(\mathrm{gr} /$ petak $)$ & $($ ton/ha $)$ \\
\hline M0 = tanpa mulsa & $8.468,75$ & 39,21 \\
M1 = mulsa Jerami Padi & $9.562,50$ & 44,27 \\
M2 = mulsa Kirinyuh & $8.656,25$ & 40,08 \\
M3 = mulsa Alang-alang & $8.612,50$ & 39,87 \\
M4 = mulsa Petai Cina & $7.556,25$ & 34,98 \\
\hline \multicolumn{1}{c}{ KK }
\end{tabular}

$\mathrm{KK}=11,24 \%$

Keterangan : $\quad$ Perlakuan tidak berpengaruh nyata terhadap produksi (ton/ha) $(\mathrm{P}>0,05)$.

Tabel 5 menunjukan bahwa rataan produksi terung tidak berpengaruh nyata terhadap perlakuan beberapa mulsa organik secara statistik $(\mathrm{P}>0,05)$. Hal ini diduga bahwa sampai akhir pene-litian pada setiap petak penelitian atau lingkungan tumbuh dan suhu lingkungan yang masih menunjang seperti unsur hara tersedia serta kebutuhan air yang mencukupi.

Menurut Harjadi (1991), bahwa ketersedian unsur hara yang cukup memungkinkan proses foto-sintensis berjalan optimum dan menghasilkan cadangan makan dalam jaringan lebih banyak, maka akan memungkinkan terbentuknya bunga atau buah yang banyak. Lebih lanjut Kadarso (2008), menyatakan bahwa penggunaan mulsa dalam budidaya tanaman dapat meningkatkan kapasitas tanah menahan air, pori aerasi dan infiltrasi serta memperta-hankan kandungan bahan organik sehingga produktivi-tas tanahnya terpelihara.

\section{KESIMPULAN DAN SARAN}

\section{Kesimpulan}

Berdasarkan tujuan dari peneli-tian ini maka didapat kesimpulan sebagai berikut :

1. Berbagai jenis mulsa organik tidak berpengaruh nyata terhadap pertumbuhan tanaman dan pro-duksi tanaman Terung (Solanum melongena L)

2. Mulsa jerami padi merupakan mulsa organik yang tepat untuk meningkatkan tinggi tanaman, jumlah buah pertanaman dan berat buah pertanaman serta produksi tanaman Terung (Solanum melongena L) varietas Ronggo.

\section{Saran}

Disarankan untuk melakukan penelitian lebih lanjut tentang mulsa organik yang lain terhadap pertum-buhan dan hasil tanaman terung

\section{DAFTAR PUSTAKA}

Badrunasar. A dan Y. Nurahmah, 2012. Pertelaan Jenis Pohon Arboretum Balai Penelitian Teknologi Agroforestry. Ba-lai Penelitian Teknologi Agroforestry. Ciamis

BPS Kabupaten Tebo. 2018. Kabupaten Tebo Dalam Angka 2018. http://tebokab. bps.go.id

BPS. 2018. Statistik Tanaman Sayuran dan Buah-buahan Semusim Indonesia 2017. http://www.bps.go.id 
Damaiyanti, D.R.R., N. Aini, dan Koesriharti. 2013. Kajian penggunaan macam mulsa organik pada pertumbuhan dan hasil tanaman cabai besar (Capsicum annuum L.). Jurnal Hortikultura 1: 25-32.

Gardner, F. P., R. B. Pearce, dan R. L. Mitchell, 1991. Fisiologi Tanaman Budidaya. Universi-tas Indonesia (UI) Press, Jakarta.

Guritno, B. \& S. M. Sitompul. 1995. Analisis Pertumbuhan Tana-man. Gajah Mada University Press, Yogyakarta.

Gusmini, Yulnafatmawita, dan A.F. Daulay. 2008. Pengaruh Pemberian Beberapa Jenis Bahan Organik Terhadap Peningkatan Kandungan Hara NPK Ultisol Kebun Percobaan Faperta Unand Padang. J. Solum Vol. V No. 2. Diunduh 10 Juli 2019

Hadi, B. A. 2018. Pengaruh Jarak Tanam Dan Mulsa Organik Terhadap Pertumbuhan Dan Hasil Tanaman Terung (Solanum melongena L.). Jur-nal Warta Edisi : 56. April 2018 | ISSN : 1829 - 7463.

Hakim, N., N. Y. Nyakpa. S. Lubis. G. Nugroho. R.Saul, M. H. Diha, Go Ban Hong dan H. H.Baley, 1986. Dasar-Dasar Ilmu Tanah. Lampung University Press, Lampung

Hardjowigeno, S. 2007. Ilmu Tanah. Akademika Pressindo. Jakarta.

Harjadi, S. S. 1991. Pengantar Agro-nomi. PT. Gramedia. Jakarta

Kadarso. 2008. Kajian Penggunaan Jenis Mulsa Terhadap Hasil Tanaman
Cabai Merah Varie-tas Red Charm. Agros 10:134-139.

Lakitan,B.2011. Dasar-Dasar Fisio-logi Tumbuhan. Raja Grafin-do Persada. Jakarta.

Mayun, I. A. 2007. Efek Mulsa Jerami Padi dan Pupuk Kandang Sapi terhadap Per-tumbuhan dan Hasil Bawang Merah di Daerah Pesisir. Agritrop. $26 \quad$ (1) : 33-40. DiunduhApril 2019

Nurdin, M., Khaidir dan Munazar. 2015. Peranan Mulsa dan Pupuk Organik Terhadap Pertumbuhan dan Hasil Kacang Tanah (Arachis hypogaea L.). Jurnal Fakultas Pertanian, Universitas Mali-kussaleh. Diunduh Desember 2019

Pujisiswanto, H. 2011. Penggunaan Mulsa Alang - Alang Pada Tumpangsari Cabai Dengan Kubis Bunga Untuk Mening-katkan Pengendalian Gulma, Pertumbuhan Dan Produksi Tanaman. Agrin Vol. 15, No. 2. ISSN: 1410-0029.

Rumakuway, D. F.J. Rumahlatu dan M.H. Makaruku. 2016. Pengaruh Jenis Mulsa Orga-nik Terhadap Pertumbuhan Dan Produksi Tanaman Sawi (Brassica juncea L.). J. Budidaya Pertanian Vol. 12(2). DiunduhApril 2019

Sarief, E.S. 2001. Kesuburan dan Pemupukan Tanah Pertanian. Pustaka Buana Bandung.

Steel, R, G, D dan J,H,Torrie. 1994. Prinsip dan Prosedur Statis-tika Suatu Pendekatan BIO Metrik. Penerbit PT. Grame-dia Pustaka Utama. Jakarta

Sunarjono, H. A., A. Soetasad dan S. Muryanti. 2003. Budidaya Terung 
Lokal dan Terung Jepang. Penebar Swadaya. Jakarta.

Suntoro. 2001. Tanaman Kirinyu

Pengganti Pupuk. Universitas

Sebelas Maret, Solo.

Surtinah. 2008. Waktu Panen yang Tepat Menentukan Kandu-ngan Gula Biji Jagung Manis (Zeamayssaccharata). Jurnal Ilmiah Pertanian 4 (2)

Tri, K dan T. Kefi. 2015. Pengaruh Mulsa Terhadap Pertumbu-han dan Hasil Kultivar Terung Lokal (Solanum Melongena, L.). Savana Cendana 1 (1) 43-46. Jurnal Pertanian Konservasi Lahan Kering. International Stan-dard of Serial Number 2477-7927.

Umboh, H.A. 2002. Petunjuk Peng-gunaan Mulsa. PT. Penebar Swadaya. Jakarta.

Wisudawati. D, M. Anshar dan I. Lapanjang. 2016. Pengaruh Jenis Mulsa Terhadap Per-tumbuhan Dan Hasil Bawang Merah (Allium ascalonicum Var. Lembah Palu) Yang Diberi Sungkup. e-J. Agrotekbis 4 (2) :126-133, Diunduh pada 24 Desember 2019. 